\title{
Effect of Pretreatments and Drying Methods on the Rehydration Ratio of Dried Mango (Mangifera Indica L.) Slices and Evaluation of Some Properties of Its Peel Flours
}

\author{
Belay Dereje* Alemu Girma \\ Department of Food Process Engineering, Wolkite University, Wolkite, Ethiopia
}

\begin{abstract}
The study was conducted to investigate the effect of selected pretreatments and drying methods on the rehydration ratio of dried mango slices and evaluation of some properties of its peel flours. Freezing and fluidized bed scored the highest rehydration values after being subjected to the pretreatments, whereas the control samples scored the lowest values. The mango peel flours had $0.49 \mathrm{~g} / \mathrm{ml}, 0.25$ and $0.11 \mathrm{ml} / \mathrm{g}$ of bulk density, water absorption and oil holding capacity respectively. The nutrient analysis showed that the mango peel flours had respective values for moisture, protein, fat, fiber, ash and carbohydrate contents $(4.62 \%, 4.28 \%, 9.18 \%, 2.25 \%$ and $70.51 \%$ ). Regarding the polyphenol of mango peel flours, the values was $564.54 \mathrm{mg}$ GAE/100g. It could be inferred that the total plate and fungal count of mango peel flours were not detected during the storage period.

Keywords: Mango drying, Rehydration; Mango peel flours; functional properties, chemical composition

DOI: $10.7176 /$ FSQM/96-01
\end{abstract}

Publication date: April $30^{\text {th }} 2020$

\section{Introduction}

Mango is a fleshy tropical fruit of highly seasonal and one of the most popular fruits of the planet (Sehrawat et al., 2018). Its the most likely fruit cultivation grown in Ethiopia (Neguse et al., 2019). However, the processing industry in Ethiopia is unbelievably weak given the large volume of mango fruit. The loss is estimated to be between 25 to $40 \%$ (Kasso and Bekele, 2018). Different strategies must be used to eat this balanced fruit all year (Neguse et al., 2019). Even if drying is attractive technology, in Ethiopia it's unknown because research and technology are not extensive (Yusufe et al., 2017).

The drying process produces many unexpected changes, such as shrinking, stiffness of texture, changes in colour and decreased usability (Abano et al., 2013). This is because drying can affect the cells, tissues and biochemical in foods which can impact the texture (Sehrawat, Nema, \& Kaur, 2016). This can reduce market value and dried food demand (Khalloufi and Maslouhi, 2000). Rehydration is a process to ensure that the property of the raw material is properly restated when the dried material contacts with water (Tedjo, Taiwo, Eshtiaghi, \& Knorr, 2002). One of the most important characteristics of dried mango slices is the capacity to rehydrate quickly and completely. Pretreating is often recommended in order to improve the quality and safety of dried goods before the drying process is carried out (Delfiya, Mohapatra, \& Kotwaliwale, N., \& Mishra, 2018).

The recovery of bioactive health benefits from fruit waste nowadays leads not only to increase the waste burden but also to satisfy the high public demand for phenolic compounds that are known to have protective effects against chronic diseases (Cheok et al., 2018). The industrial processing of agro-food products produces high amounts of waste (Castro et al., 2019). Approximately 0.5 per cent of world mango production is used for the production of derived products; hence the amount of bio-waste produced by the processing industries (Dorta, Lobo, \& González, 2012). Each year large volumes of agricultural waste are generated around the world and cause a serious disposal problem (Jawad, Alkarkhi, \& Norulaini, 2012). After processing, the mango waste is potentially problematic and forced to discard it. Though, the peels of the mango fruit currently causing pollution problems (Jawad et al., 2012). The use of mango by-products would help to reduce waste and pollutants (Adilah, Jamilah, Noranizan, \& Hanani, 2018).

Peels are the major by-products obtained during the processing of various fruits (Arumugam and Manikandan, 2011; Castro-vargas et al., 2019) and each contributes about $15-20 \%$ of the mango fruit (Gurumeenakshi et al., 2019). Research has recently been conducted on potential uses of fruit by-products such as seeds, peels. As mango peels are not currently used for any commercial purpose, they are discarded as waste and become a source of pollution in Ethiopia. Currently, several initiatives concentrate on the use of industrial waste in the production of new food ingredients with a good source of organic compounds as raw material. There is a need to develop cheap and commonly available technology for extending the shelf life of this produce (Gurumeenakshi et al., 2019). When mango peels are to be used as a raw material for the recovery of functional compounds, they must be immediately dried to avoid enzyme pectin degradation and microbial spoilage.

Peel is rich in phytochemicals, fibre and vitamin C (Gurumeenakshi et al., 2019) which makes it suitable to be processed and used in food and pharmaceuticals (Castro-vargas et al., 2019). The sensory properties and oxidative stability of fat-rich products are improved by the use of dried mango peels. In the scientific community, 
mango peels have recently attracted considerable attention due to their high content of valuable compounds, such as phytochemicals, polyphenols, carotenoids, enzymes, vitamin $\mathrm{E}$ and vitamin $\mathrm{C}$, predominantly functional antioxidant. It has also been shown that chemicals in peels of certain mango cultivars prevent the formation of fat cells by disrupting adipogenesis which is the key in the development of obesity. While these data are relevant, information on these Ethiopian mango fruits peels is lacking. Besides, studies shows that the soil, climatic conditions and varieties of different regions result in a significant difference in the composition of the fruits, and therefore data cannot simply be rented between countries. Besides, information on other vital nutrients such as functional properties, physicochemical properties, phytochemicals such as polyphenols and other such the microbial loads during storage of mango peel flours is limited if not lacking, hence this study. The data in this study may be incorporated into food nutrient databases, and also foster renewed interest in the use in product development, specifically in Ethiopia.

\section{MATERIALS AND METHODS}

Fresh, healthy and disease-free mango fruits of the Keitt cultivar used in this experiment was collected in plastic bags from Asossa, Benishangul Gumuz Regional State, Ethiopia.

\subsection{Experimental Plan}

The experiment was set in a $4 \times 4$ factorial arrangement involving four pretreatments, that were lemon juice, salt solution, hot water blanching and control (untreated) prior to drying and four drying methods (solar, tray, freeze and fluidized bed drying), arranged in a completely randomized design (CRD).

\subsection{Mango Slices Preparation}

The mangoes were cleaned, peeled and the flesh sliced manually in the direction parallel to their fibres to a thickness of approximately $5 \mathrm{~mm}$ (Adepoju \& Osunde, 2017) with a sharp stainless steel knife (Inox stainless, Brazil). These slice materials were categorized into $200 \mathrm{~g}$ each and treated with each pretreatments before drying. a) Lemon juice dips

The slices were subjected to the pretreatment of equal parts of lemon juice and distilled water mixed solution 0.5 $\mathrm{v} / \mathrm{v}$ (Abano et al., 2013) in the container (Op plastics, Ethiopia) ensuring full coverage of the slices and allowed for 10 minutes. The pretreated slices were removed from the solution and spread evenly over a perforated tray, allowing the excess solution to drip for 20 minutes.

\section{b) Hot water Blanching}

One minute hot water blanching was done by subjecting the sliced mangoes at $90^{\circ} \mathrm{C}$ (Doymaz, 2010; Wang et al., 2018) in a water bath (BM 30, Turkey) ensuring full coverage of the slices by water.

c) Salt solution dips

The samples of sliced mangoes were soaked in the solution prepared by $0.011 \mathrm{~g} / \mathrm{mL}$ (Abano et al., 2013) for 10 minutes in the container (Op plastics, Ethiopia) ensuring full coverage of the slices. The pretreated slices have been removed from the solution and spread evenly over a perforated tray, allowing the excess solution to drip for 20 minutes.

d) Control

One sample was untreated and served as the control.

\subsection{Mango Peel Flours Preparation}

The underlying pulp on the peels was removed by gently scrapping with the blunt edge of a clean knife and the peels were washed with distilled water to remove the dirt and foreign matters.

\subsection{Drying Methods}

Solar drying of mango slices was carried out in a solar dryer (YYF-2-7112P1, China). Different sides of the slices were turned to increase drying efficiency regularly. A digital hygrometer (PWT-105, China) was used to measure the temperature and relative humidity at the entrance of the collector and the drying chamber.

Tray drying of mango slices was carried out in a computer-controlled tray drying (SBANC, Madrid, Spain). The drying temperature was maintained at $70^{\circ} \mathrm{C}$.

A laboratory-scale freeze dryer (Lablyo plus, Germany) was used to dry mango slices according to Izli et al. (2017). The drying was with total pressure and the temperature inside the vacuum chamber of 52 pa and $-52^{\circ} \mathrm{C}$ respectively. The prepared slices were arranged in a single layer on the trays and placed inside the freeze dryer chamber. Thermocouple probes were used to control and monitor the product temperature on each tray during drying.

A batch type laboratory-scale fluidized bed dryer (TG 200, Germany) was used to dry the prepared mango slices and peels. An air temperature of $50^{\circ} \mathrm{C}$ and an airflow of $1.5 \mathrm{~m} / \mathrm{s}$ was set digitally (Quintana-Zaragoza et al., 2017). All the samples were dried until the moisture content of the samples dropped below $10 \%$ on a wet basis. 
The peels with average initial moisture content of $56.36 \%$ on a wet basis were dried in the fluidized bed dryer with an air temperature of $50^{\circ} \mathrm{C}$ for 90 minutes. The dried mango peels with the final average moisture content of $4.62 \%$ on weight basis was ground into a flours. The flours obtained were then sieved and enclosed in zip lock bag and stored at a room temperature until it was required for the subsequent tests.

\subsection{Data Collection}

\subsubsection{Rehydration Ratio}

Rehydration experiments were performed according to Doymaz (2010) with some modifications. In brief, about three grams of the dried products were added to $300 \mathrm{ml}$ distilled water, in a $400 \mathrm{ml}$ beaker. Samples were removed after 10, 20, 35, 60, 120 and 180 minutes, dried with tissue paper and weighed using an electronic balance.

\subsubsection{Chemical and Functional Analysis of the dried mango peel flours}

The water and oil absorption capacity and bulk density of the flour were calculated according to Sosulski et al. (1976) and Udensi, and Okoronkwo (2006), respectively.

Proximate values for moisture, fat, protein, ash, and crude fiber of dried mango peel flour samples were determined according to AOAC (2005); carbohydrate content was calculated by difference.

The $\mathrm{pH}$ of the samples was measured by dipping the electrode of a digital $\mathrm{pH}$ meter (Inolab, $\mathrm{pH} 7110$, England) into the juice of the samples after proper calibration of the $\mathrm{pH}$ meter with the standard solution. The titratable acidity was determined by titrating the aliquot with $0.1 \mathrm{~N} \mathrm{NaOH}$ solution using titration kit (Jencons digitrate pro, England) to the first appearance of pink endpoint, where phenolphthalein (3-5 drops) was used as an indicator. Using a refractometer (0-100 ${ }^{\circ}$ Brix, Bellingham Stanley Ltd., England), total soluble solids were determined directly in each sample and expressed as ${ }^{\circ}$ Brix by placing one to two drops of clear juice.

The color $\mathrm{L}^{*}, \mathrm{a}^{*}$ and $\mathrm{b}^{*}$ of the mango peel flours were measured by a colorimeter (NR110, 3NH technology co., Ltd) per CIE L*a*b* color space system. Total phenolic content was determined by spectrophotometer using Folin-Ciocalteu method following the procedure of Sogi et al. (2012).

\subsubsection{Microbial loads of the dried flour during storage}

The microbial loads of the mango peels flours were assessed during each month by using the total number of bacterial and fungal analyses (AOAC, 2005) for three months of storage period. All the colonies were counted using colony counter (362: ISO 9001: 2008 certified, England).

\subsection{Statistical analysis}

The data were analyzed using mean \pm Standard deviation analysis of variance using IBM SPSS Statistics version 20, Chicago, USA.

\section{Result and Discussion}

\subsection{Effect of Pretreatments and Drying Methods on Rehydration Ratio}

The rehydration curves for each pretreatments through the drying process are shown in Figures 1- 4. As shown in the figures, the dried mango showed high rehydration ratio and after rehydration, the sample mass was increased. Zou et al. (2013), found that the rehydration ratio values of puffed mango chips associated with different osmotic pretreatments ranged from 2.47 to 3.03 and the sample mass was doubled after rehydration. The curves showed significantly high rehydration ratio during the initial period but slowed down gradually to achieve a constant rehydration ratio. In all cases, the ratio was high at the beginning and kept on decreasing until the curve assumes horizontal position. Comparable findings have been reported by Doymaz (2010) and Yi et al. (2017) for dried apple and mango, respectively.

Nevertheless, from the pitches of the curves, at Figures 1, 2, 3 and 4 the rehydration ratio of control samples decelerates faster. The rehydration features depend on the composition of samples, preparation, processing and the degree of chemical-structural disturbances during drying (Nyangena, Owino, Ambuko, \& Imathiu, 2019). With the exception of fluidized bed, dried samples (Figure 4) hot water blanching treatments led to increase the rehydration ratio values as compared to that other pretreatments (Figures 1, 2 and 3). Similar results have been reported for apples (Doymaz, 2010) in which indicated that blanching resulted in the highest rehydration ratio as compared to citric acid and control treatments. Cellular and structural disturbances during blanching may lead to a rehydration ratio increment (Al-amin, Hossain, \& Iqbal, 2015).

The result for the freeze-dried samples after being subjected to lemon juice was in agreement with Mohamed et al. (2017) who stated that samples treated with ascorbic and citric acids had highest rehydration ratio values as compared to control samples. It could be because more rigid and porous structures have been created in lemon juice treated samples and rehydrated water filled the capillaries to reduce the resistance to deformation and thus encourage swelling and water absorption (Abano et al., 2013). In addition, samples pretreated with salt solution had the higher rehydration ratio values as compared to control samples. Similar findings were observed by (Madan \& Pare, 2014). Sodium chloride dissociates crystals, form concentrates spots of sodium and chlorine ions, and ion solvation leads to faster and improved rehydration during rehydration. Furthermore, the rehydration ratio of control 
samples was shown to be the lowest in all the four drying methods. Maldonado et al. (2010) stated dried fruit without pretreatment presents a lower rehydration ratio. An opposite result was reported in mango chips rehydration treatment by Zou et al. (2013).

The samples dried by fluidized bed dryer after subjected to all of the four pretreatments achieved better rehydration ratio. This result is also coherent with other findings of Prakash et al. (2004), who reported the highest rehydration ratio of carrots dried by fluidized bed drying whereas the lowest was that of the solar cabinet dryer. This indicated that the samples retained good texture and absorbed more water. According to Prakash et al. (2004) and Madan and Pare (2014), higher rehydration might be due to the faster drying process causes less cellular and structural changes in the final product. Freeze-dried mango samples attained better rehydration ratio as compared to solar and tray dried samples. The result obtained agreed with those of Yi et al. (2017), who observed the highest rehydration ratio of dried mango in freeze dryer. The possible reason was that the dried samples are formed with better porous structure and higher cell membranes (Wang et al., 2018). Similarly, according to Ghiafeh et al. (2007) uniform air drying and better heat transfer, resulting in fewer textural change during drying offered a higher rehydration ratio for the final product. The ability to rehydrate quickly and completely is one of the most important properties of dried mango (Akoy, 2014). Due to the reconstitution of most of the dried products before their final use, the rehydration properties of dried products are used as quality criteria to show physical and chemical changes due to the drying process (Abano et al., 2013).

Solar and tray dried samples after those pretreatments had lower rehydration ratio. Driers were likely unable to keep the drying rate constant because air temperature changes and minor shrinkage and case hardening caused less reconstitution of the dehydrated samples (Ghiafeh et al., 2007). Similarly, low rehydration can be caused by factors such as long drying times, poor product texture caused by poor relative humidity control and airflow fluctuations (Madan and Pare, 2014). The goal of drying the fruit is to make the product stable and easily handled, quickly reconstitute as close as possible to a fresh product.

The rehydration characteristics can be used as quality indices of a dehydrated product (Mishra et al., 2019). Such features reflect the changes occurring during the drying that is influenced by the sample composition, conditions imposed during the drying process and any pretreatments to which the products are subjected. Similarly, according to Maldonado et al. (2010), rehydration loss can involve losses of vitamins, sugars, amino acids, and minerals. In this work rehydration ratio of dehydrated mango slices was affected significantly by the pre-treatments and drying methods. Pretreatments and preparation of the samples before drying, drying itself, lead to changes in the structure and composition of material tissues that change reconstitution properties (Maldonado et al., 2010; Abano et al., 2013). The results of present study was in good agreement with report of Zou et al. (2013) 2.47 to $3.03 \mathrm{~g} / \mathrm{g}$, Mishra et al. (2019) 2 to $5 \mathrm{~g} / \mathrm{g}$ and Nyangena et al. (2019) 1.65 to $3.61 \mathrm{~g} / \mathrm{g}$ for dried mango. But higher than 1.62 to $2.23 \mathrm{~g} / \mathrm{g}$ that of Abano et al. (2013) for dried mango. The rehydration capacity indicates a degree of damage to foods caused by drying and were used as a quality index because they could indicate the physical and chemical changes of samples during drying (Nyangena et al., 2019). It could affect the sensorial quality of products (Q. Wang et al., 2019).

\subsection{Functional Properties of Mango Peel Flours}

The values of functional properties like bulk density, water absorption capacity and oil holding capacity are shown in Table 1. The results revealed that the mango flours had $0.49 \mathrm{~g} / \mathrm{ml}, 0.25$ and $0.11 \mathrm{ml} / \mathrm{g}$ of bulk density, water absorption and oil holding capacity respectively. The results of bulk density are comparable with the reported value of (Singh, Siddiq, Greiby, \& Dolan, 2013). The low bulk density value is always beneficial in the preparation of complementary food. The water absorption capacity indicates the mass of the water uptake per unit mass of dried flour. It play important role in the preparation of baked, fried, cooked snacks as well as flour based drinks and functional foods.

\subsection{Proximate Composition of Mango Peel Flours}

The moisture content of the dried mango peel flours was $4.62 \%$, which was in agreement with the finding of Bandyopadhyay et al. (2014) and El-Faham et al. (2016), 5.34 and 5.9\%, respectively. It was observed that the mean mango peel flours contains $4.28 \%$ of crude protein. The mean value of the fiber was $9.18 \%$. As a raw material for making fiber-rich goods, mango peel flours can be used. Fiber from mango peel is a good food fiber and can be compared with fiber from citrus (Ojokoh, 2007). Mango peels can be used to produce valuable ingredients for different food applications, as researchers have reported (Ajila et al., 2010). Similarly, according to Raghavendra et al. (2006), fibers are added to cooked meat products to improve the cooking yield owing to their water and fat retention properties and in fried food products, the addition of fiber decreases lipid retention and improves water content. Regarding the fat, ash and carbohydrates of mango peels flours were $2.37,2.25$ and $70.51 \%$, respectively. The results are comparable with previous reports by El-Faham et al. (2016) in which they have reported 2.42, 3.06 and $72.56 \%$ of fat, ash and carbohydrate for dried mango peel flour. In addition, the proximate analysis was comparable to the previous reported values in mango peel powder (Bandyopadhyay et al., 2014). 
Jawad et al. (2012) stated that mango peel was investigated for its potential as a novel and potential raw material for lactic acid production. Similarly, it has shown that a thicker, denser and continuous structured film has been produced with the addition of mango peels extract in fish gelatin (Adilah et al., 2018). Ahmad et al. (2018), concluded that mango peel powder dehydrated by different pretreatment combinations of potassium metabisulphite and ascorbic acid has maximum nutritional and sensory quality. In line with this mango peels are involved in refined food as supplements of dietary fibre, gelling and thickening agents.

\section{4. pH, Total Soluble Solids, and Titratable Acidity of Mango Peel Flours}

The $\mathrm{pH}$, total soluble solids and titratable acidity of dried mango peel flours is shown in Table 1 . The $\mathrm{pH}$ of dried mango peel flour was 4.05. It is important parameter for blending with $\mathrm{pH}$ sensitive food, such as milk and other dairy products. The titratable acidity and total soluble solids of the dried mango peel flours were $1.64 \mathrm{~g} / 100 \mathrm{~g}$ and $21.22{ }^{\circ}$ Brix, respectively. The values of $\mathrm{pH}$ and titratable acidity in the present investigation were comparable to those reported by (Singh et al., 2013).

\subsection{Color and Total Polyphenol of Mango Peel Flours}

Hunter colour values ( $\mathrm{L}^{*}, \mathrm{a}^{*}$ and $\mathrm{b}^{*}$ ) of mango peels flours are shown in Table 1. The flours had 61.75, 5.58 and 28.05 of $\mathrm{L}^{*}, \mathrm{a}^{*}$ and $\mathrm{b}^{*}$, respectively. The flour showed higher lightness and more reddish and yellow. Similar results for color values of mango peels flours were reported by (Aziah, Aziz, Wong, Bhat, \& Cheng, 2012). The phenol contents in these peels flours were $564.54 \mathrm{mg} / 100 \mathrm{~g}$ (Table 1). El-Faham et al. (2016) have reported polyphenol content of $512.62 \mathrm{mg} / 100 \mathrm{~g}$. These peels flours show high levels of polyphenol contents. Mango peel flours has been a good source of phenolic compounds from this result. Due to polyphenolic extracts, mango peels have higher values of anti-cancer properties and glucose retardation.

Moreover, mango peels have been reported as a source of rich dietary fibre, cellulose, hemicellulose, lipids, protein, enzymes and pectin (Sogi et al., 2013). In a plant that can resist oxidation, the active element is known as the phenolic and their secondary metabolites (Adilah et al., 2018).

\subsection{Microbial Loads of Mango Peels Flours during Storage}

The microbiological examination such as total plate count and fungal count of the dried mango peels were done to ensure the safety of the product and shown in Table 2. Aerobic bacteria and yeast and mould were not found in during the storage of mango peel flours for the three months. Therefore, the minimum shelf life of mango peel flours were 90 days.

\section{Conclusion}

Fluidized bed dried mango samples attained better rehydration ratio as compared to other dried samples. Except for freeze-dried samples hot water blanching treatments caused increasing in rehydration ratio values for all dried mango slices samples as compared with other treatments and control samples. The composition of mango peel flours demonstrated that it has high nutritional values as innovative functional ingredients. These results indicate that mango peel flours are rich source of carbohydrate, fiber, with good health-promoting and functional properties, thus possessing high potential to be incorporated as a functional ingredient in developing functional foods such as noodles, bread, sponge cakes, biscuits or other bakery products. The advantages of mango peels to be converted into food source can enhance the reduction of wastes, increase benefits for growers, can create jobs for people, can contribute to food security, and may encourage large scale growing of the mango fruit and industrial scale processing of products from both of the fruits and its wastes.

\section{Funding}

This research did not receive any specific grant from funding agencies in the public, commercial, or not-for-profit sectors.

\section{Competing interest statement}

The authors declare no conflict of interest.

\section{References}

Abano, E. E., Owusu, J., \& Engmann, F. N. (2013). Effects of ascorbic acid, salt, lemon juice, and honey on drying kinetics and sensory characteristic of dried mango. Croat. J. Food Sci. Technol, 5, 1-10.

Adepoju, L. A., \& Osunde, Z. D. (2017). Effect of pretreatments and drying methods on some qualities of dried mango ( Mangifera indica ) fruit. AgricEngInt: CIGR, 19(1).

Adilah, A. N., Jamilah, B., Noranizan, M. A., \& Hanani, Z. A. N. (2018). Utilization of mango peel extracts on the biodegradable fi $\mathrm{lms}$ for active packaging. Food Packaging and Shelf Life, 16, 1-7. https://doi.org/10.1016/j.fpsl.2018.01.006 
Ahmad, T., Raj, D., Mayani, J. M., Sangani, S. L., \& Patel, A. (2018). Standardize suitable pre-treatment for drying of mango peel into powder. International Journal of Chemical Studies, 6(1), 1260-1264.

Ajila, C. M., Rao, L. J., \& Rao, U. J. S. P. (2010). Characterization of bioactive compounds from raw and ripe Mangifera indica L . peel extracts. Food and Chemical Toxicology, 48(12), 3406-3411. https://doi.org/10.1016/j.fct.2010.09.012

Akoy, E. O. M. (2014). Effect of Drying Temperature on Some Quality Attributes of Mango Slices. International Journal of Innovation and Scientific Research, 4(2), 91-99.

Al-amin, M., Hossain, S., \& Iqbal, A. (2015). Effect of Pre-treatments and Drying Methods on Dehydration and Rehydration Characteristics of Carrot. Universal Journal of Food and Nutrition Science, 3(2), $23-28$. https://doi.org/10.13189/ujfns.2015.030201

AOAC. (2005). Association of Official Analytical Chemists: Official methods of Analysis of AOAC International (18th ed, Vol. 2). Washington, DC.

Arumugam, R., \& Manikandan, M. (2011). Fermentation of Pretreated Hydrolyzates of Banana and Mango Fruit Wastes for Ethanol Production. ASIAN J. EXP. BIOL. SCI., 2(2), 246-256.

Aziah, N., Aziz, A., Wong, L. M., Bhat, R., \& Cheng, L. H. (2012). Evaluation of processed green and ripe mango peel and pulp flours ( Mangifera indica var . Chokanan ) in terms of chemical composition , antioxidant compounds and functional properties. J Sci Food Agric, 92, 557-563. https://doi.org/10.1002/jsfa.4606

Bandyopadhyay, K., And, C. C., \& Bhattacharyya, S. (2014). Fortification of Mango Peel and Kernel Powder in Cookies Formulation. Journal of Academia and Industrial Research, 2(12), 661-664.

Castro-vargas, H. I., Vivas, D. B., Barbosa, J. O., Johanna, S., Medina, M., Aristizabal, F., \& Parada-alfonso, F. (2019). Bioactive Phenolic Compounds from the Agroindustrial Waste of Colombian Mango Cultivars ' Sugar Mango' and ' Tommy Atkins '- An Alternative for Their Use and Valorization. Antioxidants, 119. https://doi.org/10.3390/antiox 8020041

Cheok, C. Y., Adzahan, N. M., Rahman, R. A., Abedin, H. Z., Hussain, N., Sulaiman, R., \& Hean, G. (2018). Current trends of tropical fruit waste utilization. Critical Reviews in Food Science and Nutrition, 58(3), 335361. https://doi.org/10.1080/10408398.2016.1176009

Delfiya, A., Mohapatra, D., \& Kotwaliwale, N., \& Mishra, A. K. (2018). Effect of microwave blanching and brine solution pretreatment on the quality of carrots dried in solar - biomass hybrid dryer. Journal of Food Processing and Preservation, 42(2). https://doi.org/10.1111/jfpp.13510

Dorta, E., Lobo, M. G., \& González, M. (2012). Using drying treatments to stabilise mango peel and seed : Effect on antioxidant activity. LWT - Food Science and Technology, 45(2), 261-268. https://doi.org/10.1016/j.lwt.2011.08.016

Doymaz, Ä. (2010). Effect of citric acid and blanching pre-treatments on drying and rehydration of Amasya red apples. Food and Bioproducts Processing, 88(2-3), 124-132. https://doi.org/10.1016/j.fbp.2009.09.003

El-Faham, Ashour, M. M. S., \& Zaky, A. M. S. and A. A. (2016). utilization of mango peels as a source of polyphenolic antioxidants Utilization of Mango Peels as a Source of Polyphenolic Antioxidants. Curr. Sci. Int., 5(4), 529-542.

Ghiafeh, M., Vijayanand, P., Kulkarni, S. G., \& Ramana, K. V. R. (2007). Effect of different pre-treatments and dehydration methods on quality characteristics and storage stability of tomato powder. $L W T, 40,1832-1840$. https://doi.org/10.1016/j.lwt.2006.12.004

Gurumeenakshi, G., Varadharaju, N., \& Rajeswari, R. (2019). Quality Analysis of Mango Fruit Waste for Utilization in Food Products. International Journal of Current Microbiology and Applied Sciences, 8(03), 20-27.

Izli, N., Izli, G., \& Taskin, O. (2017). Influence of different drying techniques on drying parameters of mango. Food Sci. Technol, Campinas, 37(4), 604-612.

Jawad, A. H., Alkarkhi, A. F. M., \& Norulaini, N. A. N. (2012). Production of the lactic acid from mango peel waste - Factorial experiment. Journal of King Saud University - Science, 25(1), 39-45. https://doi.org/10.1016/j.jksus.2012.04.001

Kasso, M., \& Bekele, A. (2018). Post-harvest loss and quality deterioration of horticultural crops in Dire Dawa Region , Ethiopia. Journal of the Saudi Society of Agricultural Sciences, 17(1), 88-96. https://doi.org/10.1016/j.jssas.2016.01.005

Khalloufi, S., Y.El-Maslouhi, \& Ratti, C. (2000). Mathematical Model for Prediction of Glass Transition Temperature of Fruit Powders. Food Engineering and Physical Properties Mathematical, 65(5).

Madan, A., \& Pare, A. (2014). Drying and Rehydration Behaviour of Bamboo (Bambusa bambos) Shoots during Convective Tray Drying. Journal of AgriSearch, 11(3), 127-134.

Maldonado, S., Arnau, E., \& Bertuzzi, M. A. (2010). Effect of temperature and pretreatment on water diffusion during rehydration of dehydrated mangoes. Journal of Food Engineering, 96(3), 333-341. https://doi.org/10.1016/j.jfoodeng.2009.08.017

Mishra, M., Shukla, R. N., Kandasami, P., \& Huirem, B. (2019). Experimental Investigation on the Effect of Pre- 
Treatments on Thin Layer Drying and Quality Characteristics of Green Mangoes in Forced Convection Hot Air Drying. Int.J.Curr.Microbiol.App.Sci, 8(06), 3112-3124.

Neguse, T. B., Wanzala, F. K. R., Ali, W. M., Owino, W. O., \& Mwangi, G. S. (2019). Mango ( Mangifera indica L .) production practices and constraints in major production regions of Ethiopia. African Journal of Agricultural Research Full, 14(4), 185-196. https://doi.org/10.5897/AJAR2018.13608

Nyangena, I., Owino, W., Ambuko, J., \& Imathiu, S. (2019). Effect of selected pretreatments prior to drying on physical quality attributes of dried mango chips. Journal of Food Science and Technology, 56(8), 38543863. https://doi.org/10.1007/s13197-019-03857-9

Ojokoh, A. O. (2007). Effect of fermentation on the chemical composition of mango ( Mangifera indica R ) peels. African Journal of Biotechnology, 6, 1979-1981.

Prakash, S., Jha, S. . and, \& Datta, N. (2004). Performance evaluation of blanched carrots dried by three different driers. Journal of Food Engineering, 62, 305-313. https://doi.org/10.1016/S0260-8774(03)00244-9

Quintana-Zaragoza, L., Luna-Solano, G., Salgado-Cervantes, M. A., Jim'enez-Fernandez, M., Urrea-Garcia, G. R., \& Villegas-Santiago, J. (2017). OPTIMIZATION AND EXPERIMENTAL VALIDATION OF FLUIDIZED BED DRYING. Revista Mexicana de Ingenier'la Qu'ımica, 16(2), 625-634.

Raghavendra, S. N., Swamy, S. R. R., \& Rastogi, N. K. (2006). Grinding characteristics and hydration properties of coconut residue : A source of dietary fiber. Journal of Food EngineeringJournal of Food Engineering, 72, 281-286. https://doi.org/10.1016/j.jfoodeng.2004.12.008

Sehrawat, R., Nema, P. K., \& Kaur, B. P. (2016). Effect of superheated steam drying on properties of foodstuffs and kinetic modeling. Innovative Food Science and Emerging Technologies. https://doi.org/10.1016/j.ifset.2016.02.003

Sehrawat, R., Nema, P. K., \& Kaur, B. P. (2018). Quality evaluation and drying characteristics of mango cubes dried using low-pressure superheated steam, vacuum and hot air drying methods. LWT - Food Science and Technology. https://doi.org/10.1016/j.lwt.2018.03.012

Singh, D., Siddiq, M., Greiby, I., \& Dolan, K. D. (2013). Total phenolics , antioxidant activity , and functional properties of " Tommy Atkins' mango peel and kernel as affected by drying methods. Food Chemistry, 141(3), 2649-2655. https://doi.org/10.1016/j.foodchem.2013.05.053

Sogi, D. S., Siddiq, M., S. Roidoung, A., \& Dolan, K. (2012). Total Phenolics , Carotenoids , Ascorbic Acid , and Antioxidant Properties of Fresh-cut Mango ( Mangifera indica L ., cv . Tommy Atkin ) as Affected by Infrared Heat Treatment. Journal of Food Science, 77(11), 1197-1202. https://doi.org/10.1111/j.17503841.2012.02933.x

Tedjo, W., Taiwo, K. A., Eshtiaghi, M. N., \& Knorr, D. (2002). Comparison of pretreatment methods on water and solid diffusion kinetics of osmotically dehydrated mangos. Journal of Food Engineering, 53, 133-142.

Wang, H., Fu, Q., Chen, S., Hu, Z., \& Xie, H. (2018). Effect of Hot-Water Blanching Pretreatment on Drying Characteristics and Product Qualities for the Novel Integrated Freeze-Drying of Apple Slices. Journal of Food Quality.

Wang, Q., Li, S., Han, X., Ni, Y., Zhao, D., \& Hao, J. (2019). Quality evaluation and drying kinetics of shitake mushrooms dried by hot air, infrared and intermittent microwave-assisted drying methods. LWT - Food Science and Technology. https://doi.org/10.1016/j.lwt.2019.03.020

Yi, J.-Y., Lyu, J., Jin-Feng, Zhou, L.-Y., \& Zhou, M. (2017). Hot air drying and freeze drying pre-treatments coupled to explosion pu ffi ng drying in terms of quality attributes of mango, pitaya, and papaya fruit chips. J Food Process Preserv., 1-10. https://doi.org/10.1111/jfpp.13300

Yusufe, M., Mohammed, A. and, \& Satheesh, N. (2017). Effect of Drying Temperature and Duration on Nutritional Quality of Cochoro Variety Tomato (Lycopersicon Esculentum L.). Annals. Food Science and Technology, $18(2)$.

Zou, K., Teng, J., Huang, L., Dai, X., \& Wei, B. (2013). Effect of osmotic pretreatment on quality of mango chips by explosion puf fi ng drying. LWT - Food Science and Technology, 51(1), $253-259$. https://doi.org/10.1016/j.lwt.2012.11.005 


\section{List of table and figures}

Table 1. Some Properties of Mango Peel Flours

\begin{tabular}{|l|l|}
\hline Parameters & Contents $(\%)$ \\
\hline Moisture content & $4.62 \pm 0.24$ \\
\hline Protein & $4.28 \pm 0.04$ \\
\hline Fat & $2.37 \pm 0.16$ \\
\hline Fiber & $9.18 \pm 0.46$ \\
\hline Ash & $2.25 \pm 0.24$ \\
\hline Carbohydrate & $70.51 \pm 0.48$ \\
\hline Water absorption capacity & $0.25 \pm 0.02(\mathrm{ml} / \mathrm{g})$ \\
\hline Oil absorption capacity & $0.11 \pm 0.02(\mathrm{ml} / \mathrm{g})$ \\
\hline Bulk density & $0.49 \pm 0.03(\mathrm{~g} / \mathrm{ml})$ \\
\hline pH & $4.05 \pm 0.35$ \\
\hline Titratable Acidity & $1.64 \pm 0.07(\mathrm{~g} / 100 \mathrm{~g})$ \\
\hline Total soluble solids & $21.22 \pm 0.46\left({ }^{\circ} \mathrm{Brix}\right)$ \\
\hline L* & $61.75 \pm 0.66$ \\
\hline $\mathrm{a}^{*}$ & $5.58 \pm 0.12$ \\
\hline $\mathrm{b}^{*}$ & $28.05 \pm 0.45$ \\
\hline Polyphenol & $564.54 \pm 0.96(\mathrm{mg} / \mathrm{GAE} 100 \mathrm{~g})$ \\
\hline & \\
\hline
\end{tabular}

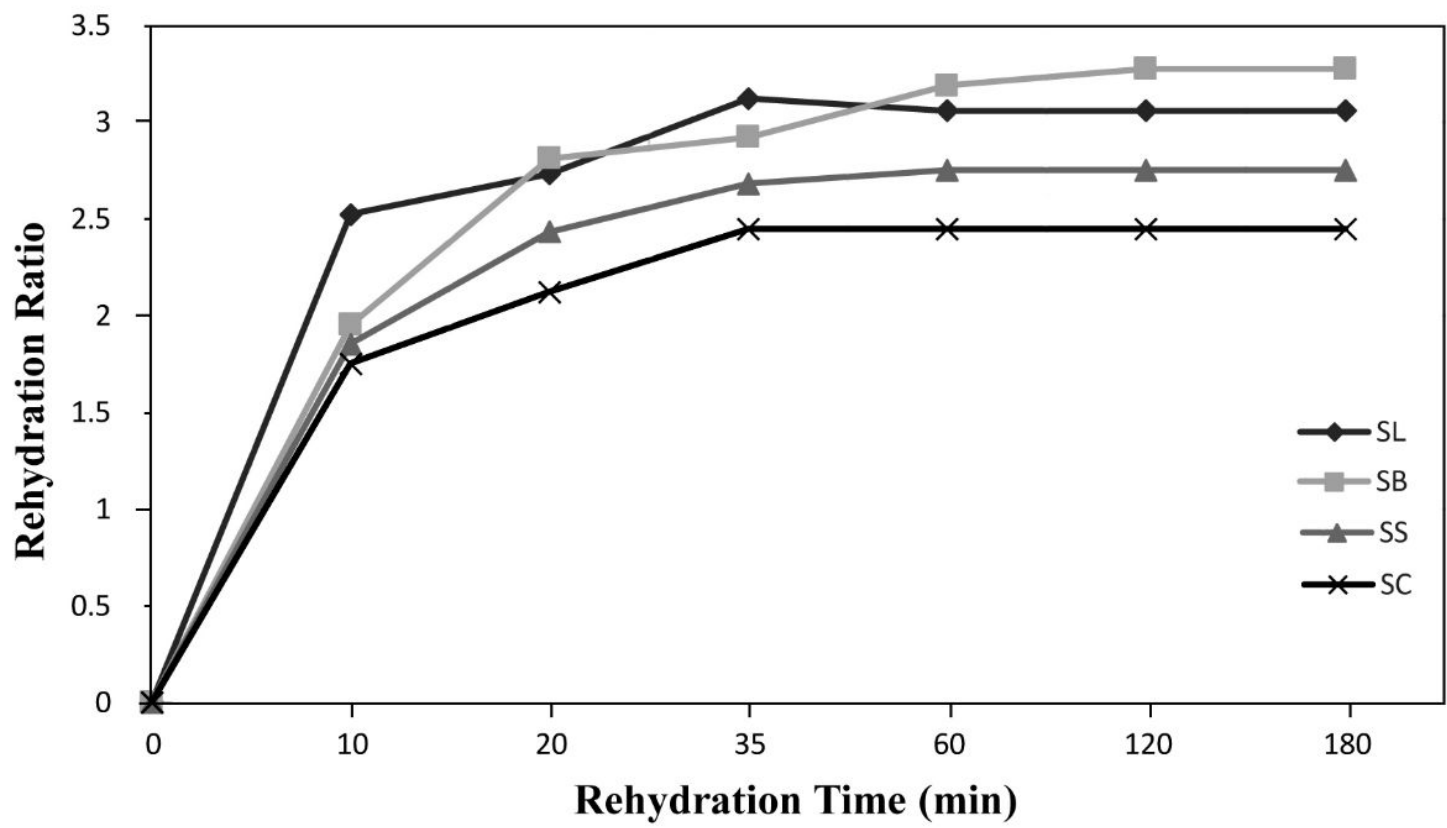

Figure 1. Rehydration curves of dried mango samples across the four pretreatments in solar drying methods. 


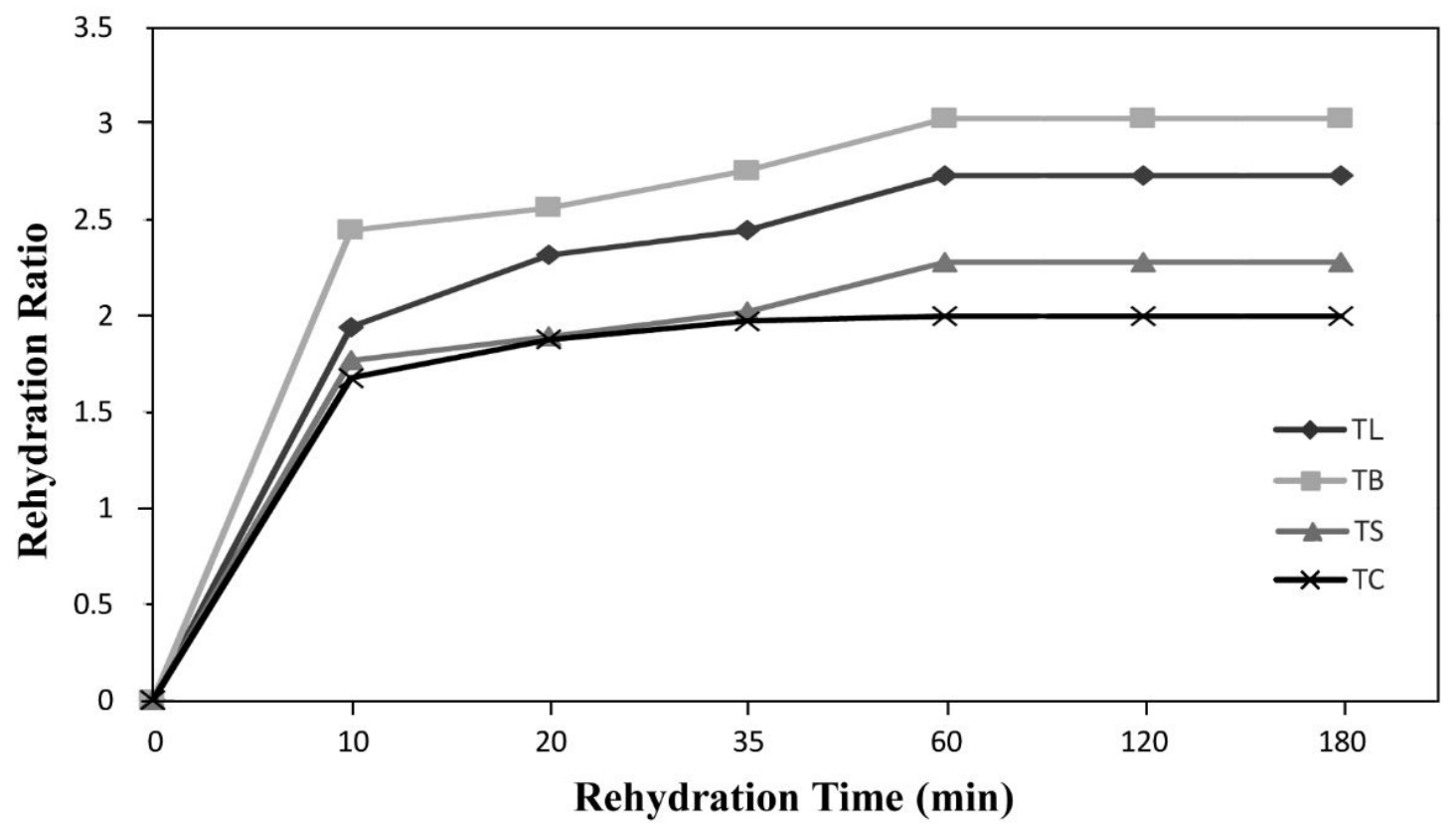

Figure 2. Rehydration curves of dried mango samples across the four pretreatments in tray drying methods.

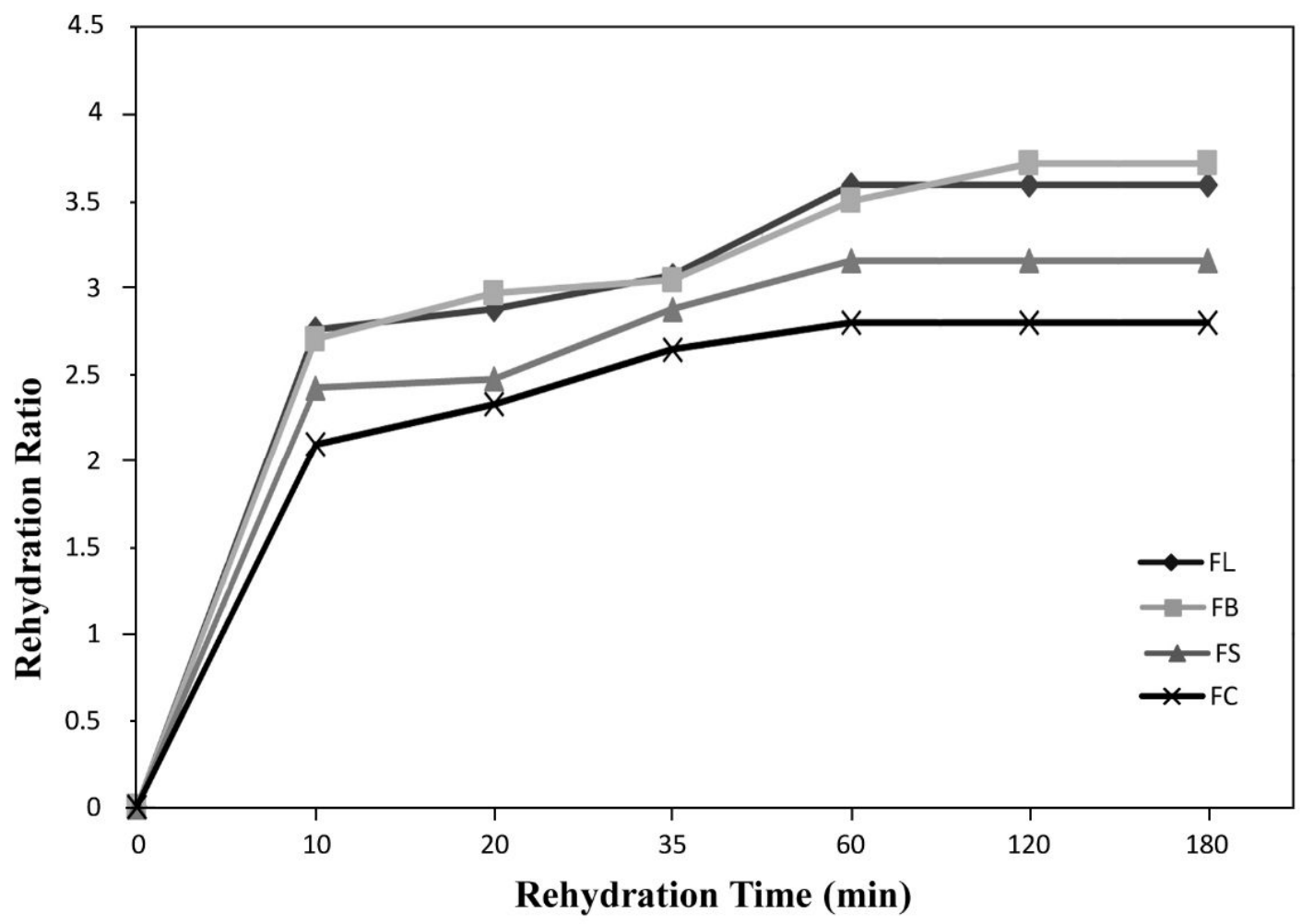

Figure 3. Rehydration curves of dried mango samples across the four pretreatments in freeze-drying methods. 


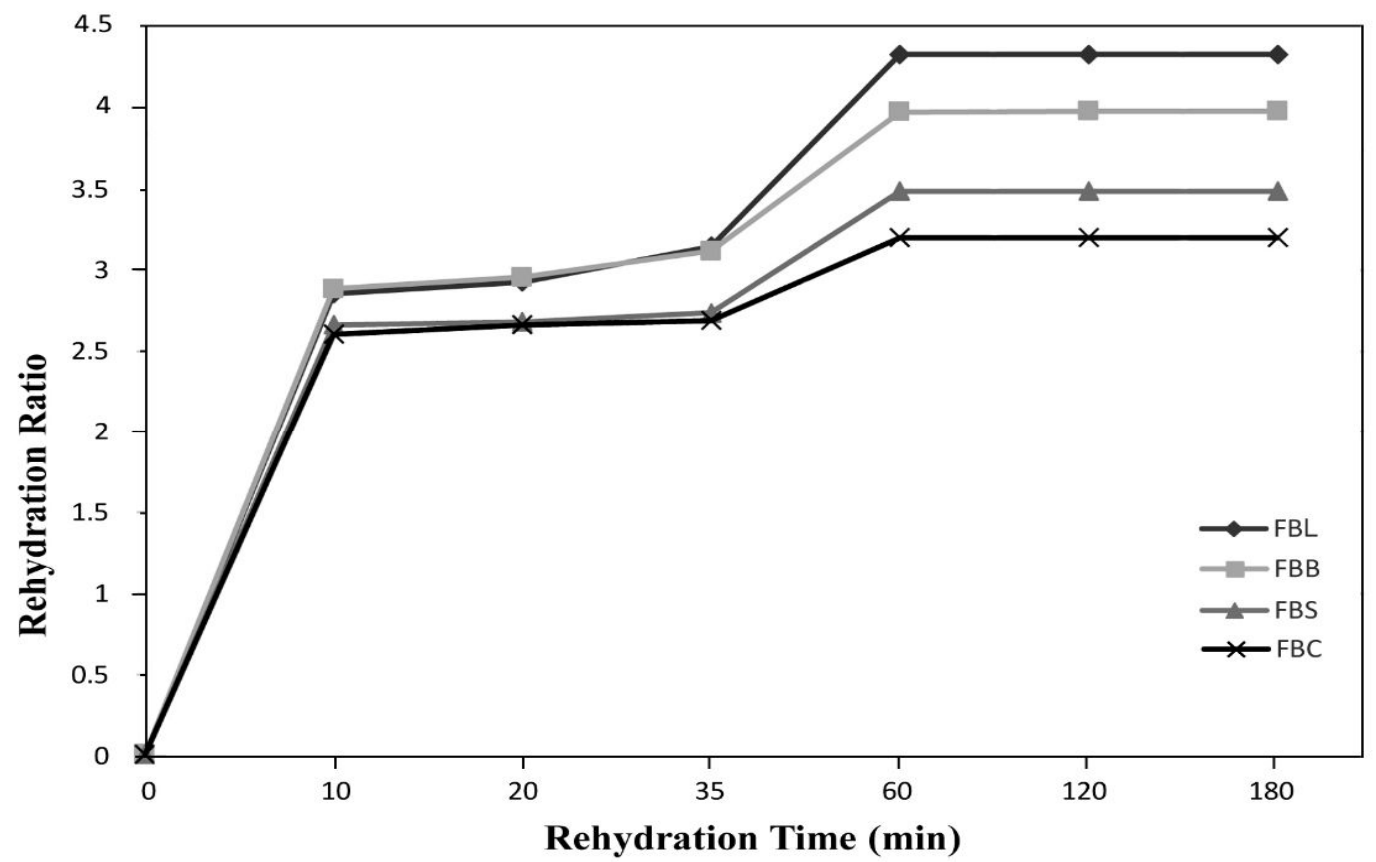

Figure 4. Rehydration curves of dried mango samples across the four pretreatments in fluidized bed drying methods. 